\title{
The Canadian Yearbook of International Law
}

\author{
VOLUME XLVII 2009 TOME XLVII
}

Annuaire canadien

de Droit international

\author{
Published under the auspices of \\ THE CANADIAN BRANCH, INTERNATIONAL LAW ASSOCIATION \\ AND \\ THE CANADIAN COUNCIL ON INTERNATIONAL LAW \\ Publié sous les auspices de \\ LA SECTION CANADIENNE DE L'ASSOCIATION DE DROIT INTERNATIONAL \\ ET \\ LE CONSEIL CANADIEN DE DROIT INTERNATIONAL
}

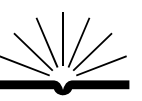

UBCPress · Vancouver - Toronto 


\section{The Definition of Damage Resulting from Transboundary Movements of Living Modified Organisms in Light of the Cartagena Protocol on Biosecurity}

\section{INTRODUCTION}

In Case Concerning Gabcikovo-Nagymaros Project (Hungary/Slovakia), the International Court of Justice found that "in the field of environmental protection, vigilance and prevention are required on account of the often irreversible character of damage to the environment and of the limitations inherent in the very mechanism of reparation of this type of damage." ${ }^{1}$ However, despite the fact that for centuries humanity has not taken into account the effects of its actions on the environment, more recently a growing number of new norms have been developed that do take such things into consideration, including the 2001 Cartagena Protocol on Biosafety (Cartagena Protocol). 2

The concept of risk and, more precisely, the concept of risk that has always been related to living modified organisms (LMOs) are dealt with in two areas. ${ }^{3}$ The first of these concepts involves

The author was a member of a research project entitled International Production and Trade of Genetically Modified Organisms, Reference no. LEo59Ao5, which was financed by the Council of Education of the Regional Government for Castilla y León. He wishes to thank Thérèse Leroux, professor at the Université de Montréal, for her support and advice during his work at the Centre de Recherche en Droit Public.

1 Case Concerning Gabcíkovo-Nagymaros Project (Hungary/Slovakia), 25 September 1997, [1997] ICJ Rep. 78.

2 Cartagena Protocol on Biosafety, 29 January 200o, 39 I.L.M. 1027 (2000). $<$ http://www.biodiv.org/biosafety/protocol.asp $>$. The list of state parties are available <http://www.cbd.int/convention/parties/list.shtml $>$ [Cartagena Protocol].

3 R. Falkner, "Regulating Biotech Trade: The Cartagena Protocol on Biosafety" (2000) $76(2)$ International Affairs 299 at 300. 
preventing or avoiding the realization of damages, even in a situation of scientific uncertainty, through the adoption of a priori measures. The second of these areas is aimed at reparation and compensation, if this harm or damage has already actually carried out, through a posteriori mechanisms.

The Cartagena Protocol aims to achieve "an adequate level of protection in the field of the safe transfer, handling and use of living modified organisms resulting from the modern biotechnology." 4 It establishes, with respect to the first type of measures, a series of previsions that regulate the advance informed agreement procedure and the transmission of information to the biosafety clearing-house. In regard to the second group of measures, the Cartagena Protocol limits itself to establishing in Article 27 a mandate for the Conference of the Parties (COP), which should undertake a process in relation "to the appropriate elaboration of international rules and procedures in the field of liability and redress." 5

During the negotiations about liability and redress for damages that led to the adoption of Article 27, the definition of damage emerged as a critical point of discussion. It is necessary here to take into account that the definition does not only need to be linked to the objective of the Cartagena Protocol, with respect to providing sufficient protection against damage to "the conservation and the sustainable use of biological diversity," but that it also needs to be coherently linked to the Convention on Biological Diversity (CBD) as well as to numerous other national and international instruments related to the protection of biodiversity. ${ }^{6}$

\section{The Controversial Question of Liability and Redress for Damages Related to Genetically Modified Organisms (GMOs)}

The majority of questions in relation to the risks related to GMOs were dealt with during the negotiations of the CBD. The text that was adopted by the CBD introduced rules in which three interrelated aspects were regulated: risks, possible damages, and restate-

4 Cartagena Protocol, supra note 2, Article 1 (Objective).

5 Ibid., Article 27 (Liability and Redress).

6 Convention on Biological Diversity, Nairobi, 22 May 1992, 31 I.L.M. 818 (1992), $<\mathrm{http}$ ///www.biodiv.org/convention/articles.asp> [CBD]. Currently, 191 states are parties to the CBD following the deposit of their ratification or accession instrument. See the status of ratifications and entry into force at $<\mathrm{http}: / /$ www. cbd.int/convention/parties/list.shtml>. 
ment. Following these rules, Principle 13 of the Rio Declaration on Environment and Development provided the mandate: "States shall develop national law regarding liability and compensation for the victims of pollution and other environmental damage."7 The elaboration of these principles, however, was followed by a series of difficult negotiations, which culminated in a new position in the regulation of the subject matter that involved the adoption of a compromise mandate in the Cartagena Protocol.

\section{THE PROVISIONS OF THE CBD}

Initially, the CDB established Article $8(\mathrm{~g})$ which invited the contracting parties to set up, or maintain, the necessary measures to regulate, administer, or control risks to the environment that would derive from the use and liberation of LMOs resulting from biotechnology, while also taking into account the risks for human health. This rule was completed by Article 14.2, which charged the COP with the task of carrying out an examination of the question of liability and restatement in relation to the damages caused to biological diversity beyond the borders of each state.

Finally, along with Article 14.2, the CBD also established, among other rules regarding various aspects of biotechnology, Article 19.3. This rule contained a mandate to adopt a protocol that would regulate adequate procedures in the sphere of the transfer, manipulation, and use of LMOs produced by biotechnology, which could have adverse effects for the conservation and sustainable use of biological diversity. ${ }^{8}$ The presence of Article 19.3 clearly reflected a compromise solution in which the signatories gave themselves a delay before adopting a regulation in the future. ${ }^{9}$ The text contains

7 Rio Declaration on Environment and Development, 13June 1992, 31 I.L.M. 874 (1992), Annex I, <http://www.unep.org/Documents.Multilingual/Default.asp ?documentID $=78$ \&articleID $=1163>$.

8 CBD, supra note 6, Article 19.3.

9 R. Falkner, "Negotiating the Biosafety Protocol: The International Process," in Chr. Bail, R. Falkner, and H. Marquard, eds., The Cartagena Protocol on Biosafety: Reconciling Trade and Biotechnology with Environment and Development? (London: Royal Institute of International Affairs and Earthscan Publications, 2002), 3 at 6; G. Henne and S. Fakir, "The Regime Building of the Convention on Biological Diversity on the Road to Nairobi” (1999) 3 Max Planck Y.B. U.N. L. 315 at 327 ; V. Koester, "The Biodiversity Convention Negotiation Process: And Some Comments on the Outcome," in E.M. Basse et al., ed., Environmental Law: From International to National Law (Copenhagen: GadJura, 1997), 205 at 222. The same article is also published in (1997) 27(3) Environmental Policy and Law 
three aspects that have clearly shaped later negotiations. ${ }^{10}$ However, it also reflects the agreement of transboundary movement of LMOs, which had negative consequences for the conservation and sustainable use of biodiversity. ${ }^{11}$

\section{NEGOTIATIONS OVER THE CARTAGENA PROTOCOL}

The awareness of the need and the forms of a possible protocol led to complex negotiations that continued over the next seven years at the heart of the Open-Ended Ad Hoc Working Group on Biosafety (BSWG), which was established by the first COP to the CBD. 12 Most authors agree that the most contentious points in the discussions, which eventually led to the breakdown of negotiations, were fundamentally related to establishing the scope of the protocol, the application of the advance informed agreement procedure, the problem of basic products, and the "highly conflictive question" of the relationship between this new instrument and other international agreements. ${ }^{13}$ Aside from these issues, however, the question of liability and restatement for damages was also a significant cause of disagreement from the outset of the negotiations. ${ }^{14}$

175 at 181 . R. Pomerance, "The Biosafety Protocol: Cartagena and Beyond" (2000) 8(3) N.Y.U. Envtl. L.J. 614 at 615.

10 A. Gupta, Framing "Biosafety" in an International Context, Environment and Natural Resources Program Discussion Paper no. E-99-10 (Cambridge, MA: Kennedy School of Government, Harvard University, 1999) at 4 .

11 O. Rivera-Torres, "The Biosafety Protocol and the WTO" (2003) 26(2) B.C. Int'l \& Comp. L. Rev. 263 at 271.

12 W. Damena, "Liability and Redress," in Bail, Falkner, and Marquard, supra note 9, 366 at 368. S. Maljean-Dubois, "Le Protocole de Carthagène sur la biosécurité et le commerce international des organismes génétiquement modifiés (OGM)" (2001) 11 (2) L'Observateur des Nations Unies 41 at 45. Liability and Redress (Article 27). Terms of Reference for the Open-Ended Ad Hoc Group of Legal and Technical Experts on Liability and Redress in the Context of the Cartagena Protocol on Biosafety: Synthesis Report of Submissions Received from Parties, Other Governments and Organizations," Doc. UNEP/CBD/BS/COP-MOP/1/9 (31 October 2003) at 2, para. 8.

13 Report of the Extraordinary Meeting of the Conference of the Parties for the Adoption of the Protocol on Biosafety to the Convention on Biological Diversity, Doc. UNEP/CBD/ ExCOP/1/3 (20 February 2000) at 27, para. 3 [CBD Report].

14 S. Burgiel, "The Cartagena Protocol on Biosafety: Taking the Steps from Negotiation to Implementation" (2002) 11 (1) R.E.C.I.E.L., 53 at 54; A. Cosbey and S. Burgiel, The Cartagena Protocol on Biosafety: An Analysis of Results, An IISD Briefing Note (Winnipeg: International Institute for Sustainable Development, 2000) 
It was in the third meeting that negotiations finally began on the issues of liability and redress. ${ }^{15}$ The representatives recognized that these issues were of crucial importance and should be considered in the future protocol. However, one member suggested that Article 14.2 of the CBD already provided a point of departure for future work in this area. ${ }^{16}$ Finally, the BSWG adopted a text that included Article 27, which referred to liability and redress and contained various options that dealt with a great variety of possibilities. ${ }^{17}$

In the sixth meeting, there was an attempt to reach a compromise position based on a document presented by the president of the working group, Kate Cook, a member of the British delegation. This position was intended to be halfway between the polarized postures that were either in favour of a system of strong liability or called for the complete suppression of the article (zero option). ${ }^{18}$ In the end, a text was approved requesting the parties to examine the modalities for the establishment and development of norms and procedures about liability and restatement. This was to be done within a period of four years from the first Meeting of the Parties (MOP). ${ }^{19}$

at 2; Rivera-Torres, supra note 11 at 272; G.W. Schweizer, "The Negotiation of the Cartagena Protocol on Biosafety" (1999-2000) 6(2) Environmental Lawyer 577 at 585 ; P.-T. Stoll, "Controlling the Risks of Genetically Modified Organisms: The Cartagena Protocol on Biosafety and the SPS Agreement" (2000) 10 Y.B.I.E.L. 82 at 87 ; S. Ladika, "Informal Talks Seen to Reaffirm Commitment of All Parties to Agree on Biosafety Protocol" (1999) 22 (22) International Environment Reporter 785 at 786 .

15 K. Cook, "Liability: "No Liability, No Protocol,"” in Bail, Falkner, and Marquard, supra note 11,371 at 378 .

16 Report of the Third Meeting of the Open-Ended Ad Hoc Working Group on Biosafety, Doc. UNEP/CBD/BSWG/3/6 (1 7 October 1997) at 10 and 11 , para. 39.

17 Secretariat of the Convention on Biological Diversity, The Cartagena Protocol on Biosafety: A Record of the Negotiations (Montreal: Secretariat of the Convention on Biological Diversity, 2003) at 82; Annex I, "Consolidated Text of Draft Articles 'Biosafety Protocol' Consolidated Text," Doc. UNEP/CBD/BSWG/3/6 (17 October 1997) at 88-9o.

18 "BSWG-6 Hightlights Tuesday, 16 February 1999" (1999) 9(112) Earth Negotiations Bulletin 2; Cook, supra note 15 at 377 .

19 Burgiel, supra note 14 at 55. P. Newell and R. Mackenzie, "The 200o Cartagena Protocol on Biosafety: Legal and Political Dimensions" (2000) 10(4) Global Environmental Change: Human and Policy Dimension 313 at 315 . The different versions revised by the Open-Ended Ad Hoc Working Group on Biosafety (BSWG) of the draft project are the following documents: Doc. UNEP/CBD/BSWG/6/L.2 and Doc. UNEP/CBD/BSWG/6/L.2/Rev.1. The final draft of the project is 
This text proved to be a great success and was to remain unaltered during the next informal consultations that took place in Vienna and Montreal in September 1999 and January 2000 respectively. In the course of the extraordinary meeting of the COP, all remaining questions were dealt with, and all significant disagreements were overcome. Finally, on 29 January 2000, the text of the Cartagena Protocol was adopted. ${ }^{20}$

THE DEVELOPMENT OF ARTICLE 27 OF THE CARTAGENA PROTOCOL

The first COP to the CBD serving as the MOP to the Cartagena Protocol established, through Decision no. BS-I/8, an Open-Ended Ad Hoc Working Group of Legal and Technical Experts on Liability and Redress (WG-L\&R), as laid out in Article 27 of the Cartagena Protocol. ${ }^{21}$ During its third meeting, the WG-L\&R focused on the channelling and limitation of liability, the canalization and limitation of liability, the mechanism of financial security, the settlement of claims, standing to bring claims, the complementary capacitybuilding measures, and the choice of the instrument.22 At the end of this third meeting, the WG-L\&R presented a blueprint of a decision of the COP-MOP on the international rules procedures in the field of liability and redress for damage resulting from the transboundary movement of LMOs. ${ }^{23}$

published in Report of the Sixth Meeting of the Open-Ended Ad Hoc Working Group on Biosafety, Doc. UNEP/ExCOP/1/2 (15 February 1999) at 32, Article 25.

20 CBD Report, supra note 13 at 33, para. 92; Falkner, supra note 9 at 22. Schweizer, supra note 14 at 580 ; S. Zarrilli, International Trade in Genetically Modified Organisms and Multilateral Negotiations: A New Dilemma for Developing Countries (Geneva: United Nations Conference on Trade and Development, 200o), Doc. UNCTAD/ DITC/TNCD/1 (5 July 200o) at 19, para. 64, <http://www.unctad.org/en/ docs/poditctncd 1.en.pdf $>$.

21 See Report of the First Meeting of the Conference of the Parties serving as the Meeting of the Parties to the Protocol on Biosafety, Doc. UNEP/CBD/COP-MOP/1/15 ( 14 April 2004) at 102-4.

22 Report of the Open-ended Ad Hoc Working Group of Legal and Technical Experts on Liability and Redress in the Context of the Cartagena Protocol on Biosafety on the Work of Its Third Meeting, Doc. UNEP/CBD/BS/WG-L\&R/3/3 (15 March 2007) at 6, paras. 34 and 36 [OEWG Liability Report].

23 OEWG Liability Report, supra note 22 at 14, Annex I, "Blueprint for a COP/MOP Decision on International Rules and Procedures in the Field of Liability and Redress for Damage Resulting from Transboundary Movements of Living Modified Organisms." 
The WG-L\&R further summarized the operational text and, with the aim of facilitating the work of the group, created two subgroups that were to work on the texts. The first of these subgroups focused on damages. ${ }^{24}$ The second subgroup worked on the administrative focus and civil liability. ${ }^{25}$ During the fifth meeting of the WG-L\&R, more detailed work was completed in this area and the text was reduced by a considerable extent. 26 The most significant development during this session was the pledge by the companies supplying biotechnological agricultural products to assume a contractual obligation to repair any damages to the biological biodiversity that were caused by their products. ${ }^{27}$ However, as had been the norm in previous negotiations about the protocol, it was necessary to continue work through a further meeting of the Friends of the CoChairs group in which the proposed norms and procedures could be negotiated in more detail. 28 The meeting was held in Bonn before the fourth meeting of the COP-MOP, and it succeeded in creating a document with a revised structure and with significant changes in different sections, including the section related to damages. ${ }^{29}$

24 Report of the Open-Ended Ad Hoc Working Group of Legal and Technical Expert on Liability and Redress in the Context of the Cartagena Protocol on Biosafety on the Work of Its Fourth Meeting, Doc. UNEP/CBD/BS/WG-L\&R/4/3 (13 November 2007) at 4 , para. 18.

25 Ibid.

26 Report of the Open-Ended Ad Hoc Working Group of Legal and Technical Expert on Liability and Redress in the Context of the Cartagena Protocol on Biosafety on the Work of Its Fifth Meeting, Doc. UNEP/CBD/BS/WG-L\&R/5/3 (25 March 2008) at 9, para. $5^{6 .}$

27 This offer was made by Thomas Carrato of the Global Industry Coalition, on behalf of BASF, Bayer CropScience, Dow AgroSciences, DuPont/Pioneer, Monsanto and Syngenta. Ibid. at 7 , para. 36 .

28 Ibid. at 13, para. 88. Final Report of the Open-Ended Ad Hoc Working Group of Legal and Technical Experts on Liability and Redress in the Context of the Cartagena Protocol on Biosafety, Addendum on Proposed Operational Texts on Approaches and Options Identified Pertaining to Liability and Redress in the Context of Article 27 of the Biosafety Protocol: Outcomes of the Meeting of the Friends of the Co-Chairs, Bonn, 7-Io May 20o8, Doc. UNEP/CBD/BS/COP-MOP/4/11/Add.1 (11 May 2008) at 1, para. 1 [Addendum on Operational Texts].

29 Addendum on Operational Texts, supra note 28 at 1, para. 2. Report of the Fourth Meeting of the Conference of the Parties to the Convention on Biological Diversity serving as the Meeting of the Parties to the Cartagena Protocol on Biosafety, Doc. UNEP/CBD/ BS/COP-MOP/4/18 (10 June 2008) at 23 and 24, para. 154 [Report of the Fourth Meeting]. 
Finally, the fourth meeting of the COP-MOP, which was held during May 2008, approved Decision no. IV/12 in which a Group of the Friends of the Co-Chairs Concerning Liability and Redress in the Context of the Cartagena Protocol on Biosafety (GF-L\&R) was established. This group had the mandate of finalizing the negotiation of the norms and procedures in this area in a meeting, which was held in February 2009. ${ }^{30}$

\section{The Definition of Damage in the Context of Article 27 of the Cartagena Protocol}

The development of rules related to liability and restatement for damages in accordance with the Cartagena Protocol requires a clear definition of "damage." 31 Unlike other international texts that deal extensively with damages, Article 27 only mentions the source of damage, referring to "damage resulting from transboundary movements" of LMOs. ${ }^{32}$ As such, the concept and extent of damage needs to be defined in the context of the entire Cartagena Protocol. ${ }^{33}$

Closely linked to the definition of damage is a series of other questions such as whether the extent of damage as understood in Article 27 covers damage to the environment, to people, or to goods since the text of the Cartagena Protocol only makes reference to "adverse effects on the conservation and sustainable use of biological diversity." 34 Furthermore it does not clarify what should be understood by "conservation and sustainable use." The question arises as to whether this reference to "damage to the conservation and sustainable use of biological diversity" is different from "damage to biological diversity" as contained in paragraph 3 of the preamble, and, furthermore, whether "taking into account risks to human health" implies the inclusion of personal damages such as

30 Report of the Fourth Meeting, supra note 29 at 82, para. 1, Decision no. BS-IV/ 12 on Liability and Redress under the Cartagena Protocol on Biosafety.

31 E. Duall, "A Liability and Redress Regime for Genetically Modified Organisms under the Cartagena Protocol" (2004) 36(1) Geo. Wash. Int"l L. Rev. 173 at 193 .

32 Identification of Issues Relating to Liability and Redress for Damage Resulting from the Transboundary Movement of Living Modified Organisms, Doc. UNEP/CBD/WSL\&R/1/2 (4 November 2002) at 5, para. 23 [Identification of Issues].

33 Ibid. at 6, para. 6. Duall, supra note 31 at 194.

34 See Cartagena Protocol, supra note 2 at Articles 1, 2.4, 4, 7.4, 10.6, $11.8,12.1$, $15.1,16.2,16.5$ (a) $, 17.1,17.3$ (c) $, 17.4,18.1,21.6(\mathrm{c}), 23.1$ (a), 26.1 , and Annex III on Risk Assessment. 
the costs of medical treatment in the concept of damage as recounted in the rules of the Cartagena Protocol. Similarly, it is necessary to clarify whether the reference in Article 26 to "socioeconomic considerations arising from the impact of living modified organisms on the conservation and use of biological diversity" allows us to interpret these types of considerations within the notion of damage. 35

Aside from the absence of a definition, there is also a lack of sufficient precedents that could provide an idea of the nature and the extent of "transgenic damages." 36 Consequently, in order to establish a system of liability and compensation for damages derived from the transboundary movement of LMOs, it is necessary to demarcate aspects such as the nature and extent of the uncertain risks observed during an ample period of time in order to arrive at an understanding of damage.

THE CONCEPT OF DAMAGE IN OTHER INTERNATIONAL LAW PROCESSES

The Intergovernmental Committee for the Cartagena Protocol on Biosafety (ICCP) took on the study of the international norms and procedures in accordance with the mandate contained in Article 27 of the Cartagena Protocol. ${ }^{37}$ The study focused on the current multilateral treaties relating to liability and compensation for damages. The texts are very limited in nature and concentrate on damage to health and to property in transboundary contexts. They refer to nuclear damage, hydrocarbon contamination, and the transport of dangerous goods and substances and objects from space. ${ }^{38}$ They

35 Identification of Issues, supra note 32 at 6, para. 30.

36 Ibid. at 3, para. 14. C. Kummer Peiry, "International Civil Liability for Environmental Damage: Lessons Learned," in C. Kummer Peiry et al., Liability and Redress and Living Modified Organisms: A Contribution to the Article 27 Process under the Cartagena Protocol on Biosafety (Brussels: CropLife International, 2004), 11 at 19 , $<$ http:/ / www.ecoconsult.ch/uploads/1 144-Croplife_Handbook.pdf >.

37 Liability and Redress for Damage Resulting from the Transboundary Movements of Living Modified Organisms. Review of Existing Relevant Instruments and Identification of Elements, Doc. UNEP/CBD/ICCP/2/3 (31 July 2001) at 1 [Liability and Redress for Damage]. Kummer Peiry, supra note 36 at 11.

38 Determination of Damage to the Conservation and Sustainable Use of Biological Diversity, Including Case-Studies, Doc. UNEP/CBD/BS/WG-L\&R/2/INF/3 ( 1 February 2006), Annex: Definitions of "Damage" or Related Concept from Other International Agreements at 16-20. 
take into account indemnification for loss of life or personal injury, damage to property, and damage or harm to the environment. In this last case, liability for transboundary environmental damage has also been considered and has been introduced by amendments into the original texts. ${ }^{39}$

While the texts dealing with nuclear damage and with damages resulting from hydrocarbon contamination have been very effective since the 1960 os and 1970 , none of the texts dealing with other dangerous substances have entered into effect as they have not received the necessary number of ratifications and have, as such, been considered "dead letters." 40

With respect to the first group mentioned earlier - nuclear damage - the Protocol to Amend the Vienna Convention on Civil Liability for Nuclear Damage should be mentioned. ${ }^{41}$ It expanded the concept of "nuclear damage" contained in Article 2 of the 1963 Vienna Convention on Civil Liability for Nuclear Damage to cover environmental damage and economic loss caused by nuclear damage, which includes the following: economic loss related to personal damages or damage to property; the cost of restoring a damaged area of the environment; the loss of income due to an economic interest in any use of the environment resulting from significant damage to the environment; and the cost of preventative measures. ${ }^{42}$ With respect to liability and redress for hydrocarbon contamination, the Protocol to Amend the International Convention on Civil Liability for Oil Pollution Damage incorporates into the 1969 International Convention on Civil Liability for Oil Pollution Damage damage to the environment and loss of profit stemming from damages but limited "to costs of reasonable measures of reinstatement actually undertaken or to be undertaken." 43

39 Liability and Redress for Damages, supra note 37 at 4, para. 12.

40 Kummer Peiry et al., supra note 36 at 11.

41 Protocol to Amend the Vienna Convention on Civil Liability for Nuclear Damage, Vienna, 12 September 1997, 36 I.L.M. 1462 (1997). The protocol to amend the Vienna Convention was signed by fifteen states and was ratified by five of these states, thereby reaching the minimum number required by Article 21 in order to come into force. This occurred on 4 October 2003. To consult the ratification process, see <http://www.iaea.org/Publications/Documents/Conventions/protamend_status.pdf>.

42 Vienna Convention on Civil Liability for Nuclear Damage, 2 I.L.M. 727 (1963).

43 Protocol to Amend the International Convention on Civil Liability for Oil Pollution Damage, London, 27 November 1992, UN Doc. LEG/CONF.9/15 (2 December 1992). The protocol has been in force since 30 May 1996 and has 
The new generation of rules relating to liability for the environment emerged at the end of the 1980 os and during the 1990 . These agreements were the subject of complex negotiations before finally being accepted, and none have yet to come into force. ${ }^{44}$ In regard to the relative liability for the transport of dangerous goods and substances, the Convention on Civil Liability for Damage Caused during Carriage of Dangerous Goods by Road, Rail and Inland Navigation Vessels includes among "damages" the following in Article 1.10: loss of human life or injury; the loss of, or damage to, property; damage to the environment through contamination; and the cost of preventative measures. The redress for the damages caused to the environment is limited "to costs of reasonable measures of reinstatement actually undertaken or to be undertaken." 45

The Convention on Civil Liability for Damage Resulting from Activities Dangerous to the Environment is the treaty that provides the most developed and complete coverage in regard to liability and redress for damage to the environment. ${ }^{46}$ In Article 2.7, damage is defined as that which is done to people and property, losses or damages due to harm done to the environment, and the cost of preventative measures. Elsewhere, the understanding of the term "environment" is now extended to include "natural resources both abiotic and biotic, such as air, water, soil, fauna and flora and the interaction between the same factors; property which forms part of the cultural heritage; and the characteristic aspects of the landscape." 47

been signed up to a significant number of states. See the list of parties at $<\mathrm{http}$ :/ / www.imo.org $/$ Conventions $/$ mainframe.asp?topic_id $=256 \&$ doc_id $=660>$. International Convention on Civil Liability for Oil Pollution Damage, 29 November 1969, 9 I.L.M. 46 (1970).

44 Kummer Peiry et al., supra note 36 at 15 .

45 Convention on Civil Liability for Damage Caused during the Carriage of Dangerous Goods by Road, Rail and Inland Navigation Vessels, Geneva, 10 October 1989, <http://www.unece.org/trans/danger/publi/crtd/crtd_e.html > at Article 1.10.c. This convention has only been signed by two states: Germany and Morocco, and has only been ratified by one non-signatory state: Liberia. Since the minimum required by Article 23 was not reached, it is not yet in force.

46 Convention on Civil Liability for Damage Resulting from Activities Dangerous to the Environment, Lugano, 21 June 1993, 32 I.L.M. 1228 (1993) [Lugano Convention]. Currently, this convention is signed by only nine states: Cyprus, Finland, Greece, Iceland, Italy, Liechtenstein, Luxembourg, Netherlands, and Portugal, and it has only been ratified by Portugal. It is currently not in force.

47 Lugano Convention, supra note 46 , Article 2.10. 
The International Convention on Liability and Compensation for Damage in Connection with the Carriage of Hazardous and Noxious Substances by Sea states in Article 1.6 that damages are the loss of life or personal injury, the loss of property or damage to it, and losses or damages due to contamination of the environment and costs of preventative measures. ${ }^{48}$ Compensation is said to be limited "to costs of reasonable measures of reinstatement actually undertaken or to be undertaken."

As for the Basel Protocol on Liability and Compensation for Damage Resulting from Transboundary Movements of Hazardous Wastes and Their Disposal (Basel Protocol), this text defines "damage" in its second article as: the loss of life or personal injury; the loss of or damage to property; the loss of income directly as a result from an economic interest in any use of the environment; the costs of repairing damage to the environment - these being limited to the costs of the measures that were actually used - and, finally, the cost of preventative measures. ${ }^{49}$ The measures of reinstatement of an impaired environment are defined as the reasonable measures to assess, reinstate, or restore damaged or destroyed components of the environment. However, the Basel Protocol goes further and, in Article 3, extends the application of the term "to damage due to an incident occurring during a transboundary movement of hazardous wastes and other wastes and their disposal, including illegal traffic, from the point where the wastes are loaded on the means of transport in an area under the national jurisdiction of a State of export." The Basel Protocol was adopted after ten years of negotiations and has many similarities to the Cartagena Protocol since it was not possible to include rules of liability in the Basel Protocol, and the parties were requested to consider this question at a later date. ${ }^{50}$

48 International Convention on Liability and Compensation for Damage in Connection with the Carriage of Hazardous and Noxious Substances by Sea, London, 3 May 1996, 35 I.L.M. 1406 (1996).

49 Basel Protocol on Liability and Compensation for Damage Resulting from Transboundary Movements of Hazardous Wastes and Their Disposal, Basel, 10 December 1999, <http://www.basel.int/meetings/cop/cop5/docs/prot-e.pdf > . The Basel Protocol was signed up to by thirteen states and was ratified by nine states, thereby reaching the minimum number of twenty required by Article 29.1 in order to come into force. See the status of ratifications at $<\mathrm{http}: / /$ www.basel. int/ratif/protocol.htm>.

50 P. Lawrence, "Negotiation of a Protocol on Liability and Compensation for Damage Resulting from Transboundary Movements of Hazardous Wastes and Their Disposal" (1998) 7(3) R.E.C.I.E.L. 249 at 249. 
Finally, in the context of liability for space objects, the Convention on Liability for Damage Caused by Space Objects only considers liability for damages caused by space objects and does not include damage to the environment in accordance with the definition of damage in its Article 1 (a). ${ }^{51}$

\section{THE IDEA OF DAMAGE TO BIODIVERSITY}

Considering the remit of the Cartagena Protocol and in accordance with Article 27, it is now useful to focus on the risks of causing damage to biological diversity. 52 The environmental impact of GMOs can be studied using a framework based on the causes of change in ecosystems and in biodiversity - taking into account that GMOs constitute one of the main causes of the extinction of organisms. 53 These causes are applicable to GMOs in accordance with the idea of loss of biodiversity contained in Decision no. VII/ 30 of the COP to the CDB. These include habitat change caused by variation in the use of the terrain, in the use of rivers or water extracted from rivers, or contamination and the introduction of invasive alien species. 54

Along with the changes of habitats, contamination has been highlighted as one of the main causes for the loss of biological diversity. This is due to the use of herbicides, pesticides, and fertilizers that have caused great harm in many parts of the world. ${ }^{55}$ One of

51 Convention on International Liability for Damage Caused by Space Objects, London, Moscow, Washington, 29 March 1972, (1972) 66 A.J.I.L. 702. This convention was ratified by ninety signatory states and was also signed by another twenty-three states that have not yet ratified. However, this convention is the most accepted instrument in the field of responsibility.

52 Cartagena Protocol, supra note 2, Article 6.1 excludes from the application of procedures of the advance informed agreement for "the transboundary movement of living modified organisms destined for contained use undertaken in accordance with the standards of the Party of import."

53 P. Raven, "The Epic of Evolution and the Problem of Biodiversity Loss," in Ch. McManis, ed., Biodiversity and the Law: Intellectual Property, Biotechnology and Traditional Knowledge (London: Earthscan, 2007), 27 at 30.

54 Decision no. VII/30 on a Strategic Plan: Future Evaluation of Progress, Report of the Seventh Meeting of the Conference of the Parties to the Convention on Biological Diversity, Doc. UNEP/CBD/COP/7/2 1 (13 April 2004) at 379. Millennium Ecosystem Assessment, Ecosystems and Human Well-Being: Biodiversity Synthesis (Washington, DC: World Resources Institute, 2005) at 8, <http://www.millenniumassessment. org/en/Synthesis.aspx>. J. Chen, "Across the Apocalypse on Horseback: Biodiversity Loss and the Law," in McManis supra note 53, 42 at 43 .

55 Millennium Ecosystem Assessment, supra note 55 at 8 . 
the great indirect benefits of GMOs is the reduction of pesticides. These results, however, have not been the same for all of the GMO crops due to the fact that some require additional pesticides as they are not resistant to all species of weeds. Furthermore, some species have developed particularly strong resistance and have turned into literal "superweeds," which has led to the necessity of applying additional herbicides and pesticides. ${ }^{56}$ Nevertheless, it is important to point out that this applies to both traditional and GMO crops.

Finally, one of the biggest risks facing biodiversity is "invasive alien species." These are considered to be one of the greatest dangers for the extinction of species and for biodiversity. ${ }^{57}$ These effects would also lead to changes in the environment caused when a new organism replaces another species in the area.58 GMOs should not be considered "invasive," yet changes can occur in the network of ecological relationships that can cause an organism to become invasive and then to damage the plants in the area of analysis. 59

Various criteria have been proposed for measuring the invasiveness of GMOs, including the changes in the adaptation characteristics, the adverse effects of the flow or transfer of genes, the adverse effects for non-objective organisms, genotypic or phenotypic instability, and, finally, their capacity to combine with viruses. ${ }^{60}$ Various studies, however, have shown that GMO crops do not have the capacity to invade habitats that are superior to that which has the non-modified version of these crops. ${ }^{61}$ This research indicates that the agricultural crops do not survive for much time outside of their cultivation. To conclude, it is necessary to be mindful that the

56 International Union for the Conservation of Nature (IUCN), Current Knowledge of the Impacts of Genetically Modified Organisms on Biodiversity and Human Health: An Information Paper (Gland, Switzerland: IUCN, August 2007) at 26, <http:// cmsdata.iucn.org/downloads/ip_gmo_o9_2007_1_.pdf >.

57 Chen, supra note 54 at 45 . IUCN, Guidelines for the Prevention of Biodiversity Loss Caused by Alien Invasive Species as Approved by 5 Ist Meeting of Council, February 20oo, Information Paper (May 2000) at 2, <http://www.issg.org/infpaper_invasive. pdf $>$.

58 This is the concept of damage that was put forward in the submission from the government of Norway. Liability and Redress (Article 27), Doc. UNEP/CBD/BS/ COP-MOP/1/INF/5 (8 December 2003) at 21.

59 L.L. Wolfenbarger and P.R. Phifer, "The Ecological Risks and Benefits of Genetically Engineered Plants" (15 December 2000) 290 Science 2088 at 2088.

60 IUCN, supra note 56 at 27 .

61 Ibid. at 27 . 
potential risks and benefits of GMO plants are inevitably quite uncertain and depend a great deal upon the complexity of the ecological systems that can vary in space and time and according to the modification of the crop. 62 An objective evaluation of the risks is particularly difficult due to the fact that natural and human modified systems are very complex and are destined to remain unclear until extensive tests about their introduction have been carried out. 63

The WG-L\&R examined the question of damage to biological diversity, and a series of conclusions were reached, which can be summarized in the following points:

- that a mere change in the state of biological diversity might not necessarily constitute damage - to constitute damage the change must result in an adverse or negative effect that should be measurable;

- that information on baseline conditions for determining and measuring change is often not available, and, in its absence, other methodologies for measuring change would be needed; and

- that some environmental changes do not manifest themselves immediately so that the issue of linking actors and long-term environmental effects also arises. ${ }^{64}$

Evidently, the risks involved in the introduction of GMOs into a new ecosystem need to be examined in a case-by-case approach, along with appropriate risk management measures such as the implementation of the precautionary approach and of suitable mechanisms such as the pest risk assessment introduced by the International Plant Protection Convention. 65

62 Wolfenbarger and Phifer, supra note 59 at 2090.

63 IUCN, supra note $5^{6}$ at $3^{1}$.

${ }^{64}$ Report of the Group of Legal and Technical Experts on Liability and Redress in the Context of para. 2 of Article I4 of the Convention on Biological Diversity, Doc. UNEP/CBD/ COP/8/27/Add.3 (18 October 2005) at para. 19.

65 International Plant Protection Convention, Rome, 6 December 1951, <http:// www.ippc.int/ippctypo3_test/index.php?id $=1110485 \& \mathrm{~L}=0>$. IUCN, supra note $5^{6}$ at 31 . See the criteria outlined in "Pest Risk Analysis for Quarantine Pests Including Analysis of Environmental Risks and Living Modified Organisms: ISPM No. 11 ," in International Standards for Phytosanitary Measures I to 3 I (Rome: Food and Agriculture Organization, 2008), Annex 3: Determining the Potential for a Living Modified Organism to Be a Pest, 137, particularly at 159 and 160 , 


\section{Elements for a Definition of Damage Resulting from Transboundary Movements of LMOs}

The different areas of risk that have been referred to earlier, taking into account the concepts of damage proposed in the international agreements, have been systemized in a large number of operational texts based on the definition of damage presented in the headquarters of the WG-L\&R. These texts were summarized by the WG-L\&R, listing the following components in the definition of damage:

- damage to conservation and sustainable use of biological diversity or its components;

- damage to the environment;

- damage to human health;

- socio-economic damage, especially in relation to indigenous and local communities;

- traditional damage; and

- costs of response measures. ${ }^{66}$

Following this summary in the final report of the WG-L\&R, these categories were grouped into two sections in the proposed operational texts on approaches and identified options. The first of these was related to the definition of damage in the context of an administrative approach to the liability of states in the context of the Cartagena Protocol and the second was the concept of damage in the context of the demand for civil liability under the protection of national rights. 67

<https://www.ippc.int/servlet/BinaryDownloaderServlet/34163_ISPM_11_E. pdf?filename $=1146658377367$ ISPM 11 .pdf\&refID $=34163>$. The International Plant Protection Convention entered into force on 3 April 1952. At a later date, two texts, revised in 1979 and 1997, were signed. All the authentic texts are available online at <https:/ / www.ippc.int/servlet/CDSServlet?status=NDoxMzI 5 MiY2PWVuJjMzPSomMzc9a29z $>$.

66 Synthesis of Proposed Texts and Views on Approaches, Options and Issues Identified Pertaining to Liability and Redress in the Context of Article 27 of the Biosafety Protoco, Note by the Co-Chairs, Doc. UNEP/CBD/BS/WG-L\&R/2/2 (19January 2006) at 14 [Synthesis of Proposed Texts]. Synthesis of Proposed Operational Texts on Approaches, Options and Issues Identified (Sections I to III) Pertaining to Liability and Redress in the Context of Article 27 of the Biosafety Protocol, Doc. UNEP/CBD/BS/WG-L\&R/3/2 / Add.1 (20 December 2006) at 14 [Synthesis of Proposed Operational Texts]. OEWG Liability Report, supra note 22 at 29.

67 See Final Report of the Open-Ended Ad Hoc Working Group of Legal and Technical Experts on Liability and Redress in the Context of the Cartagena Protocol on Biosafety, 
Since they were required to do so by Decision no. BS-IV/ 12 of the COP-MOP, the distinction has been discussed and developed by the GF-L\&R in two draft documents. ${ }^{68}$ The first of these documents was the Supplementary Protocol on Damage to the Conservation and Sustainable Use of Biological Diversity Resulting from Transboundary Movements of Living Modified Organisms to the Cartagena Protocol on Biosafety, and the second was entitled Guidelines on Civil Liability and Redress in the Field of Damage Resulting from Transboundary Movements of Living Modified Organisms. 69

DEFINITION OF DAMAGE FOR AN ADMINISTRATIVE APPROACH:

THE DAMAGE TO CONSERVATION AND SUSTAINABLE USE OF BIOLOGICAL DIVERSITY

As Argentina, the United States, and the European Union (EU) have clearly stated, since Article 27 of the Cartagena Protocol did not clearly contain a definition of damages, it is necessary to refer to Article 1 (Objective) and Article 4 (Scope) of the protocol, which both refer to "adverse effects on the conservation and sustainable use of biological diversity, taking also into account risks to human health."70 In this sense, the damage, which is referred to in Article 27 , should be understood as damage to the conservation and sustainable use of biological diversity - there being an important distinction between the former and the latter. ${ }^{71}$ Indeed, as is already done in some of the operational texts, the definition should be reduced simply to the impact on biological diversity. 72

Damage to the conservation of biological diversity should be approached by taking into account the following three aspects: first, the definition of biodiversity proposed by the CDB; second, the concept of loss of biodiversity according to the definition stated in

Doc. UNEP/CBD/BS/COP-MOP/4/11 (7 April 2008) at 8 [Final Report of the $O E W G]$.

68 Report of the Fourth Meeting, supra note 29 at 84 .

69 Report of the Group of the Friends of the Co-chairs on Liability and Redress in the Context of the Cartagena Protocol on Biosafety on the Work of Its First Meeting, Doc. UNEP/ CBD/BS/GF-L\&R/1/4 (27 February 2009) at 5, Annex I and II [Report of the Group of the Friends]

70 Synthesis of Proposed Operational Texts, supra note 66 at 15 and 16.

$71 \mathrm{Ibid}$. at 16 . UNEP/CBD/BS/WG-L\&R/3/2/Add.1, n. 65 above, at 15 , Operational text 2 ; and at 17 , Operational text 7 .

72 Synthesis of Proposed Operational Texts, supra note 66 at 17 , Operational Text no. 8. 
Decision no. VII/30,73 which is "reducing the rate of loss of the components of biodiversity, including: (i) biomes, habitats and ecosystems; (ii) species and populations; and (iii) genetic diversity"; and, third, the idea of the costs of the reinstatement measures. ${ }^{74}$

When considering damage to the sustainable use of biological diversity, it is necessary to estimate that there are many different forms of sustainable use of biological diversity, and, thus, the term needs to cover agriculture, horticulture, silviculture, livestock, hunting, gathering, and recreational exploitation. ${ }^{75}$ Considering the proposal made by the United States, it was stated that the damage to biological diversity, in its conservation as well as its sustainable use, should be identified by the change in a variable. That is to say, the change should be measurable or observable, and the change should be negative. ${ }^{76}$

The possible integration of damage to the environment in this concept of damage was taken up in some of the proposals. 77 However, the reference was contested by some governments who understood that there was no reference to this in the Cartagena Protocol. According to Argentina, the protocol made mention of the conservation and sustainable use of biological diversity but did not mention the "environment" in general terms. ${ }^{78}$ Similarly, the EU and the Global Industry Coalition suggested that there was a superimposition with the idea of conservation and sustainable use of biological diversity. 79

Subsequently, the WG-L\&R moved to define damage, from an administrative perspective, as "damage to the conservation and the sustainable use of biological diversity, taking also into account risks to human health, resulting from transboundary movement of LMOs." $"$ It also proposed that both damage to the conservation and to the sustainable use of biological diversity implies, in terms

73 See note $5^{6}$ in this article and adjacent text.

74 Synthesis of Proposed Operational Texts, supra note 66 at 16.

75 Ibid. at 16 .

76 Ibid. at 17 . Addendum on Operational Texts, supra note 28 at 4.

77 Synthesis of Proposed Operational Texts, supra note 66 at 15, Operational Text no. 1; and at 18, Operational Text no. 9 .

78 Synthesis of Proposed Operational Texts, supra note 66 at 19.

79 Ibid. at 19 .

80 Final Report of the OEWG, supra note 67 at 8 . Addendum on Operational Texts, supra note 28 at 3 and 4 . 
of the text, an adverse or negative effect on biological diversity. In the case of damage to conservation, it is necessary to verify that it is measurable or otherwise observable, and that it is significant. In the case of damage to sustainable use, it is necessary to verify that there has been a loss of income or that there has been a consequential loss to a state, including loss of income. ${ }^{81}$ From this affirmation we can deduce that, according to the WG-L\&R, the essential difference between damage to conservation and damage to sustainable use is the verification of indirect damages to a state, including the loss of income.

Ultimately, this interpretation was omitted in Article 2(d) of the Supplementary Protocol on Damage to the Conservation and Sustainable Use of Biological Diversity Resulting from Transboundary Movements of Living Modified Organisms to the Cartagena Protocol on Biosafety, which was proposed by the GF-L\&R. It concludes by defining damage in the following terms:

(d) Damage to the conservation and sustainable use of biological diversity [in relation to the administrative approach as contained in Articles $\mathrm{xx}-\mathrm{xx}$ [sic] means an adverse effect on biological diversity that:

(i) Is measurable or otherwise observable taking account, wherever available, scientifically established baselines recognized by a competent national authority that takes into account any other human induced variation and natural variation; and

(ii) Is significant as set out in paragraph 3 below [this definition of damage shall be without prejudice to the domestic law of parties in the field of civil liability]. 82

DEFINITION OF DAMAGE FOR A GIVIL LIABILITY: DAMAGE TO

HUMAN HEALTH, SOCIO-ECONOMIC DAMAGE, AND TRADITIONAL

DAMAGE

In the report of the WG-L\&R, various aspects appeared linked to the idea of damage in accordance with the Cartagena Protocol. These aspects included damage to human health, socio-economic damage, traditional damage, and, finally, as we have already mentioned, the cost of the response measures. Damages to human health include aspects such as the loss of life or personal damages, the loss

81 Addendum on Operational Texts, supra note 28 at 3 .

82 Report of the Group of the Friends, supra note 69 at 9. 
of income, measures of public health, and the deterioration of health. ${ }^{83}$ Some argued that this provision would be in keeping with Article 4 of the protocol, which perceived the need for "taking also into account risks to human health." For others, this was to be a rule that would come into play when it was necessary to evaluate the risks, keeping in mind this category of damages. ${ }^{84}$ Other sectors, such as the EU, understood that this type of damage would overlap with aspects that fell within "traditional damage" and considered that these, or some of them, should be dealt with at a national level. 85

Similarly, the definition of damage should take into account damages of a socio-economic nature, which would cover the loss of income, the loss of cultural, social, or spiritual values, the loss of safety in foodstuffs, and the loss of competitiveness. 86 There were also many divergent opinions, from Argentina and the Global Industry Coalition, which considered that socio-economic damage per se did not come under the jurisdiction of the Cartagena Protocol and that there is only one mention of socio-economic considerations in Article 26, which allows them to be taken into account when it comes to adopting a decision prior to the first transboundary movement. ${ }^{87}$ For others, such as Canada and the EU, it was not clear how this definition of damage could be differentiated from the traditional concept of damage and to what extent it would superimpose on other components of damage. ${ }^{88}$

In accordance with the synthesis of proposed texts and views on approaches, options, and issues, the concept of traditional damage included the loss of life or personal damage; the loss of, or damage to, property; and economic loss. ${ }^{89}$ In some proposals, it was felt that damage should also reflect the interpretation of the term contained

$83 \mathrm{UNEP} / \mathrm{CBD} / \mathrm{BS} / \mathrm{WG}-\mathrm{L} \& \mathrm{R} / 2 / 2$, n. 65 above, at 20. UNEP/CBD/BS/WGL\&R/3/2/Add.1, n. 65 above, at 15 , Operational text 1 and Operational text 2; at 18 , Operational text 9 .

84 Synthesis of Proposed Operational Texts, supra note 66 at 20.

85 Ibid. at 21.

86 Ibid. at 14. Synthesis of Proposed Operational Texts, supra note 66 at ${ }_{15}$, Operational Text no. 1; and at 18, Operational Text no. 9 .

87 Synthesis of Proposed Operational Texts, supra note 66 at 23 and 24.

88 Ibid. at 23 and 24. Synthesis of Proposed Operational Texts, supra note 66 at 16 , Operational Text no. 3; and at 18, Operational Text no. 9 .

89 Synthesis of Proposed Operational Texts, supra note 66 at 14; and at 16, Operational Text no. 3 . 
in the actio legis aquiliae, which is the actio ex contractu arising from the Cartagena Protocol and from the actio damni injuriae. ${ }^{90}$ However, this appraisal has been equally problematic since, as was pointed out earlier, the EU maintains that some of its components overlap with other components of damage such as damage to the sustainable use of biological diversity and damage to human health. ${ }^{91}$ Finally, the definition of damage would include the costs of the response measures. These measures are not in themselves a category of damage but, according to the EU and Norway, they are considered relevant for the rest of the categories and should be covered by the rules and procedures that are referred to in Article 27 of the Cartagena Protocol. ${ }^{92}$ Furthermore, from the perspective of Greenpeace International, this was a logical consequence of the application of the "polluter pays principle." 93

The scope of the response measures is described in some of the operational texts, and it would include any reasonable measures taken by any person, including public authorities, following damage that has occurred, or to prevent, minimize, or mitigate possible loss or damage, or to arrange for environmental clean-up. ${ }^{94}$ In light of all of these proposals and arguments, the GF-L\&R grouped these categories under the heading "civil liability," which, in broad terms, would be composed of the "damage resulting from the transboundary movement of LMOs to legally protected interests as provided for by domestic law, including damage not redressed through administrative approach (no double recovery)."95 The Guidelines on Civil Responsibility and Redress propose a description of the norms and procedures related to damage in accordance with national rights in the following terms:

(1) These rules and procedures apply to damage [resulting from the transboundary movement of LMOs] as provided for by domestic law.

(2) For the purposes of these rules and procedures, damage [resulting from the transboundary movement of LMOs] as provided for by domestic law may, inter alia, include:

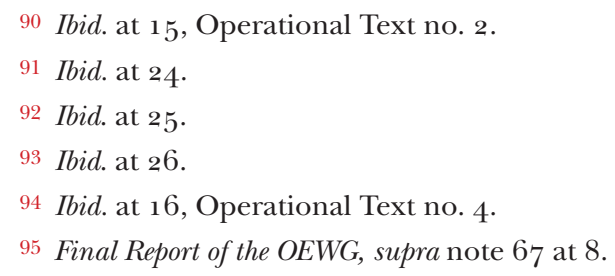


(a) Damage to the conservation and sustainable use of biological diversity not redressed through the administrative approach;

(b) Damage to human health, including loss of life and personal injury;

(c) Damage to or impaired use of or loss of property;

(d) Loss of income and other economic loss [resulting from damage to the conservation or sustainable use of biological diversity];

(e) Loss of or damage to cultural, social and spiritual values, or other loss or damage to indigenous or local communities, or loss of or reduction of food security. 96

\section{Conclusion}

During the past several years, intensive negotiations have taken place in order to develop a mandate resulting from Article 27 of the Cartagena Protocol, which itself had emerged as a compromise solution. It would appear that, finally, nine years after the protocol was accepted, an agreement has been achieved regarding the scope of the problematic concept of damage in the context of the transboundary movement of LMOs.

Considering the difficulties that have caused by the uncertainty related to the risks deriving from LMOs and the lack of precedents in this area, it has nevertheless been possible to achieve a very relevant systematization of the complex reality of the diverse damages that could be caused by the transboundary movements of LMOs. In light of the international texts related to the responsibility of states in different areas, a clear distinction has been established between two areas - the first being related to the responsibility of the state from an administrative perspective and the second being the claim for civil responsibility as a channel for redress and restatement to individuals. Another significant step in this area has been the proposal from the Group of the Friends of the Co-Chairs, developed in their Supplementary Protocol on Damage to the Conservation and Sustainable Use of Biological Diversity Resulting from Transboundary Movements of Living Modified Organisms to the Cartagena Protocol on Biosafety and in the Guidelines on Civil Responsibility and Redress.

The more ambitious goal of reaching a more precise definition of damage to the conservation of biological diversity and of damage to the sustainable use of biological diversity remains, for the

96 Report of the Group of the Friends, supra note 69 at 19. 
moment, on the negotiating table. It is possible that the most effective approach is to leave a large margin for interpretation so that a case-by-case approach can be taken.

Similarly, it would be desirable to incorporate to the concept of damage to the conservation and sustainable use of biological diversity the cost of the measures of reinstatement in the same way that occurs with instruments such as the Basel Protocol on Liability and Compensation. However, perhaps it is preferable to develop an instrument that would have a wide consensus and that would at least achieve the acceptance of the LMO-producing countries. If not, it is likely that the whole process will become bogged down in endless negotiations that will only result in "dead letters."

Juan-Francisco Escudero Espinosa University of León, León, Spain

\section{Sommaire}

La définition de préjudice résultant de mouvements transfrontières d'organismes vivants modifiés à la lumière du Protocole de Cartagena sur la biosécurité

La notion de risque nécessite des mesures préventives ainsi que des mesures de responsabilité et de réparation dans le cas de préjudice. Le Protocole de Cartagena sur la biosécurité se limite, à l'article 27 , à l'établissement d'un mandat pour l'élaboration des normes et procédures en matière de responsabilité et de réparation. L'accomplissement de ce mandat exige, d'abord, une définition de la notion de préjudice à la conservation et l'utilisation durable de la diversité biologique; d'autre part, une enquête sur l'étendue du préjudice à la santé; et, troisièmement, un examen d'aspects socio-économiques. Dans ce contexte, cet article analyse la notion de préjudice dans les instruments internationaux qui traitent de cette matière, en tenant compte des niveaux de l'implantation. L'article conclut en présentant une définition de préjudice, pour utilisation dans le cadre de l'élaboration du contenu de l'article 27 , en se fondant sur une orientation administrative en ce qui concerne la notion de préjudice tiré de la responsabilité civile en droit interne. 
Summary

The Definition of Damage Resulting from Transboundary Movements of Living Modified Organisms in the Light of the Cartagena Protocol on Biosecurity

The concept of risk requires preventative measures as well as measures of liability and redress in the case that damage is actually caused. The Cartagena Protocol on Biosecurity limits itself in Article 27 to the establishment of a mandate for the elaboration of norms and procedures in regard to liability and redress. The fulfillment of this mandate requires, first, a definition of the concept of damage to the conservation and sustainable use of biological diversity; second, a survey of the extent of damage to health; and, third, the consideration of socio-economic aspects. In this context, this article analyzes the concept of damage in the international instruments that deal with this material, taking into account levels of implantation. The article concludes by presenting a definition of damage for use in the context of the development of the content of Article 27, using an administrative focus in regard to the concept of damage for civil liability in domestic law. 